\title{
NAUCZANIE POLSKIEJ DEKLINACJI I SKLADNI W GRUPACH WSCHODNIOSŁOWIAŃSKICH
}

Słowa kluczowe: język polski jako obcy, kontrast językowy, nauczanie kontrastywne, deklinacja, składnia, osoby rosyjskojęzyczne, studenci ze Wschodu

Streszczenie. W niniejszym tekście omówiono nauczanie deklinacji i składni polskiej w ujęciu kontrastywnym na przykładzie nauczania osób dorosłych ze Wschodu, znających język rosyjski jako język pierwszy lub drugi. Przedstawiając kontekst teoretyczny nauczania J2 w kontraście z J1, akcentuje się, że współcześnie korzystamy zarówno ze zdobyczy analiz kontrastywnych J1 i J2, jak i analizy błędów i znajomości zjawiska interferencji. Przedstawia się postulat konfrontatywności w nauczaniu JPJO osób ze Wschodu, który przewija się przez całą polskojęzyczną literaturę glottodydaktyczną.

W artykule zaprezentowano techniki dydaktyki polskiej deklinacji i składni w kontraście z językiem rosyjskim zaczerpnięte z książki autorki Polski dla nas 1. Польский для нас 1. Deklinacja i sktadnia kontrastywnie dla Stowian wschodnich (A2-B2). Podzielono je na dwie grupy: ćwiczenia jednojęzyczne i dwujęzyczne. Zwrócono przy tym uwagę, iż znajomość J1 grupy uczących się przez lektora znacząco wspomaga nauczanie w kontraście, jednak nie jest warunkiem sine qua non tego typu dydaktyki.

\section{WSTĘP}

W 1983 roku J.P.B. Allen pisał, iż

każda z powszechnie stosowanych metod nauczania gramatyki [...] może okazać się w pewnych sytuacjach szczególnie przydatna; należy jednak zdawać sobie sprawę, że żadna $\mathrm{z}$ tych metod nie jest kompletna sama w sobie i że większość sytuacji nauczania

*dominika.izdebska-dlugosz@uj.edu.pl, Uniwersytet Jagielloński, Wydział Polonistyki, Zakład Językoznawstwa Stosowanego, Instytut Glottodydaktyki Polonistycznej, ul. Grodzka 64, 31-044 Kraków. 
wymaga łączenia wszystkich [...] podejść. Podstawowym zadaniem nauczyciela jest

znalezienie właściwego połączenia metod działania w każdych okolicznościach.

(1983, s. 81)

Słowa wypowiedziane w latach 80. są aktualne dziś jeszcze mocniej-w dobie eklektyzmu i pluralizmu metodycznego wybór odpowiedniej metody nauczania języka obcego, a najczęściej metod kombinowanych podyktowany jest specyfiką danej grupy odbiorców i potrzebami językowymi jej członków.

W niniejszym artykule wyraża się przekonanie, że dydaktyka języków obcych i drugich (dalej: J2) pokrewnych i podobnych do języków pierwszych (dalej: J1) przynosi lepsze efekty przy wykorzystaniu kontrastu językowego J1 i J2 - szczególnie dotyczy to procesu budowania kompetencji językowej - dydaktyki gramatyki J2. Na przykładzie języka polskiego jako obcego (dalej: JPJO) dla użytkowników języków wschodniosłowiańskich prześledzono techniki nauczania polskiej deklinacji i składni w językowo-strukturalnym kontraście z językiem rosyjskim (jako podstawie porównań międzyjęzykowych). Rozważania rozpocząć musi jednak refleksja nad istotą kontrastu językowego oraz jego praktycznym zastosowaniem w dydaktyce języków obcych.

\section{OD HIPOTEZY KONTRASTYWNEJ DO DYDAKTYKI JEZZYKA OBCEGO W KONTRAŚCIE}

\subsection{HIPOTEZA KONTRASTYWNA}

Ustalenie zasad nauczania języka obcego w kontraście z J1 uczącego się wymaga cofnięcia się do okresu powstania samej hipotezy kontrastywnej i studiów kontrastywnych. Za ich początek uznaje się rozprawę R. Lado Linguistics Across Cultures (1957), w której autor przedstawił założenia hipotezy kontrastywnej powstałej na gruncie behawioryzmu. Zakładała ona, że trudności językowych w nauce J2 jest tym więcej, im J2 mocniej różni się od J1 uczącego się. Uważano zatem, iż im większe są różnice strukturalne pomiędzy J1 a J2, wchodzącymi w kontakt w procesie uczenia się J2, tym więcej uczący się popełnia błędów językowych w J2. Konstatacja ta zrodziła glottodydaktyczne nadzieje w zakresie prognozowania potencjalnych błędów językowych w J2 uczącego się, a wynikających z interferencji językowej. Uwierzono bowiem w prostą zależność: ,interferencja jest odwrotnie proporcjonalna do stopnia podobieństwa między porównywanymi elementami” (Krzeszowski 1979a, s. 587-588). 
Lingwistyczny model powstawania błędu R. Lee (1969) zakładał, że znajomość J2 oznacza właściwie przyswojenie różnic między J1 i J2 (Komorowska 1980, s. 96). Ten „strukturalno-behawiorystyczny” model koncentrował się na J1 uczącego się jako jedynym źródle trudności w nauce J2 i przyczynie błędów językowych w języku obcym. Na długo ukierunkował on rozumienie błędu językowego w J2 (jako zjawiska wysoce niepożądanego), a także stał się bodźcem do podejmowania licznych analiz kontrastywnych różnych par języków. W latach 70. uważano, iż dzięki analizom kontrastywnym możliwa jest prognoza błędów językowych oraz ich pełna profilaktyka (Korzeniewska-Rogalewicz 1986, s. 27). Badania empiryczne szybko jednak zadały kłam teoretycznym analizom kontrastywnym. Okazało się, iż podobieństwa strukturalne pomiędzy J1 i J2 także są przyczyną błędów w J2. Udowodniono ponadto, że błędy w J2 występują nie tylko w miejscach przewidzianych przez analizy kontrastywne, ale pojawiają się także na obszarach przez nie w ogóle nie uwzględnionych (Bednarska 2014, s. 19; Komorowska 1980, s. 98). Zbiory błędów prognozowanych w toku analiz kontrastywnych i wyłonionych w badaniach empirycznych jedynie się zazębiały, a nie pokrywały, co podważyło wartość prognostyczną analiz kontrastywnych (Komorowska 1980, s. 97). Wyrazem tego rozczarowania stały się aktualne do dziś słowa L. Newmarka:

Lekarstwem na interferencję językową jest po prostu lekarstwo na niewiedzę, tzn. uczenie się. Nie istnieje żadna szczególna potrzeba zwalczania interferencji ze strony języka ojczystego ucznia, co było bardziej lub mniej wyraźnym usprawiedliwieniem studiów kontrastywnych, które, zdaniem lingwistów, mają być niezbędne dla planowego nauczania języków.

(Marton 1979, s. 607)

Problematykę badań kontrastywnych i ich aplikacji dydaktycznych w Polsce podejmowali m.in. T.P. Krzeszowski oraz W. Marton, który już w latach 70. postulował połączenie ich wyników ze zdobyczami kognitywizmu w dydaktyce języków obcych (Korzeniewska-Rogalewicz 1986, s. 28-31). To właśnie kognitywizm przyniósł glottodydaktyce zrozumienie roli świadomości uczącego się w procesie nauki J2 - w tym także świadomości dotyczącej źródła własnych błędów językowych i miejsc w J2 szczególnie podatnych na występowanie interferencji.

\subsection{INTERFERENCJA JĘZYKOWA A PODOBIEŃSTWO J1 I J2}

Dziś przyjmuje się, iż to właśnie bliskość J1 i J2 jest warunkiem wystąpienia interferencji. Obok stopnia otwartości podsystemu języka, rodzaju przyswajanej struktury, typu tekstu oraz stopnia rozwoju interjęzyka to właśnie stopień 
pokrewieństwa pomiędzy językiem prymarnym a docelowym, a co za tym idzie genetyczne i typologiczne podobieństwo języków, jest czynnikiem warunkującym w znacznym stopniu interferencję interlingwalną (Arabski 1980, s. 13).

Uważa się także, że pojawienie się transferu negatywnego jest warunkowane istnieniem zbieżności między J1 i J2 (Harczuk 1972a, s. 11, 1972b, s. 204, 205; Arabski 1980, s. 12). Oprócz faktycznego podobieństwa J1 i J2 istotne jest również przekonanie uczącego się o zbieżności J1 i J2 noszące miano dystansu psychotypologicznego, mogącego także istotnie wpływać na siłę interferencji poprzez hipergeneralizację (Otwinowska-Kasztelanic 2009, s. 191-196), gdy dostrzeżone pomiędzy J1 a J2 podobieństwo zostaje rozszerzone na sferę różnic między dwoma systemami (Czochralski 1979, s. 523). Zatem to właśnie w przypadku języków podobnych interferencja działa najmocniej, powodując występowanie większej liczby błędów interlingwalnych w produkcji językowej, ułatwiając zarazem znacząco kształcenie sprawności receptywnych. Stąd powstawanie tak charakterystycznego rozdźwięku pomiędzy poziomem sprawności produktywnych i receptywnych, czego znakomitym przykładem są uczący się JPJO Słowianie wschodni.

W przypadku nauczania J2 zbliżonego do J1 to właśnie kontrast językowy, który zawdzięczamy analizom konstrastywnym, może być wykorzystany w walce z błędami transferu negatywnego - tymi, które występują w polszczyźnie studentów ze Wschodu.

\subsection{NAUCZANIE GRAMATYKI J2 W KONTRAŚCIE Z J1}

W dydaktyce języka obcego można wyróżnić dwie strategie związane z obecnością J1 uczącego się: strategię separacyjną (izolacja od J1) i strategię asymilacyjną (J1 jako punkt odniesienia, baza do porównań - Kaczmarski 2003, s. 14). Jednak nawet jeśli w procesie dydaktycznym J1 uczącego się zostanie całkowicie wyeliminowany (co miało miejsce w metodzie audiolingwalnej), to uczeń „W dalszym ciągu będzie [...] dokonywał bardziej lub mniej świadomie, swoistego thumaczenia tworzonego przez siebie tekstu, a przynajmniej różnych jego elementów z języka ojczystego na obcy. Proces ten, zdefiniowany za pomocą terminu tlumaczenie myślowe / mental translation dotyczy przede wszystkim gramatyki” (Kaczmarski 2002a, s. 18). Rozsądniejsze zatem wydaje się wykorzystanie tego naturalnego zjawiska, a paralelne ujęcia elementów gramatyki J1 i J2 będą wspomagały naukę J2, gdyż - jak pisał Krzeszowski:

korzystając ze swojej znajomości gramatyki języka ojczystego [...] [uczący się] będzie miał dużo łatwiejsze zadanie ucząc się gramatyki [J2], niż gdyby miał się jej uczyć nie korzystając zupełnie z nabytej dotąd wiedzy, to znaczy w całkowitym oderwaniu od gramatyki języka ojczystego. 


\section{JEZZYK POLSKI JAKO OBCY DLA UŻYTKOWNIKÓW JĘZYKÓW WSCHODNIOSŁOWIAŃSKICH}

\subsection{POSTULOWANA KONFRONTATYWNOŚĆ}

Nie jest przypadkiem, iż o konieczności nauczania JPJO w kontraście z J1 uczących się zaczęto mówić po 1989 r., wraz z napływem do naszego kraju Polaków ze Wschodu i równoczesnym wysyłaniem polskich nauczycieli do krajów byłego ZSRR. Wówczas to dostrzeżono i opisano specyficzne problemy tej grupy uczących się w licznych artykułach w tomach pokonferencyjnych (Mazur 1992, 1993, 1995, 1996). Od początku akcentowano konieczność nauczania języka polskiego osób z byłych republik radzieckich w kontraście ze znanymi im językami słowiańskimi, wówczas głównie z językiem rosyjskim. J. Mazur pisał: „W odniesieniu do Polaków ze Wschodu podstawowym błędem metodycznym jest brak konfrontatywnego przedstawiania materiału gramatycznego, ułatwiającego wyjaśnienie istoty i przyczyn najczęstszych błędów językowych” (1995, s. 33). Podobną opinię wyrażała B. Krucka: ,[... ] celowym wydaje się poznawanie systemu językowego polszczyzny w ujęciu konfrontatywnym - w zestawieniu z systemem języka rosyjskiego. Dotyczy to zwłaszcza tych obszarów gramatyki, w których istnieją jednoczesne podobieństwa i różnice [...]" (1995, s. 123).

Postulat konfrontatywności w nauczaniu JPJO Słowian - szczególnie wschodnich - przewija się w glottodydaktyce polonistycznej od lat 70. do dziś (zob., np.: Krzeszowski 1979b; Kowalikowa 1992; Biełocka 1997; Jabłońska 2004; Krawczuk 2005, 2011; Paradowski 2006; Izdebska-Długosz 2015, 2018; Seretny 2018). Pomocne w rozpoznawaniu problemów osób rosyjskojęzycznych uczących się polszczyzny są omówienia trudności i potrzeb Polaków uczących się języka rosyjskiego jako obcego - to zagadnienie dobrze opracowane, gdyż - chronologicznie - wcześniejsze (do 1989 r.). O wskazywaniu różnic i podobieństw językowych, walce z błędami transferu pisało wielu polskich rusycystów (Doros, Łużny 1965; Harczuk 1972; Siatkowski 1976; Skrundowa 1985; Grochowski 1990; Karolczuk 2006).

Istotnym czynnikiem decydującym o wyborze podejścia komparatystyczno--kontrastywnego jest także wiek uczących się. To oczywiste, iż ze względu na nikłe działanie interferencji i dominację myślenia konkretnego takie podejście nie sprawdzi się w nauczaniu JPJO młodszych dzieci. Przyniesie jednak rezultaty u starszych dzieci, młodzieży (pod warunkiem operowania przez uczestników procesu dydaktycznego gramatycznymi abstraktami), a przede wszystkim u dorosłych. Nie bez znaczenia są także czynniki psychologiczne: „Osobnik dojrzały uczy się skuteczniej, jeżeli procesowi zdobywania wiedzy 
towarzyszy porządkująca i interpretująca refleksja intelektualna [...]. Osoby dorosłe mają skłonność do porządkowania nowej wiedzy przez odnoszenie jej do tego, co znane" (Kowalikowa 1992, s. 52).

\subsection{KONTRASTYWNIE, CZYLI JAK?}

Trudno się zgodzić z opinią, iż dydaktyka w ujęciu kontrastywnym to po prostu używanie obok J2 także J1 uczącego się lub innych języków obcych. Obecność thumaczenia eksplikatywnego, np. poleceń do ćwiczeń czy objaśnień gramatycznych na J1 uczącego się, nie jest w żadnym wypadku strategią kontrastywną. $Z$ dydaktyką języka obcego w ujęciu kontrastywnym lub konfrontatywnym ${ }^{1}$ mamy do czynienia wówczas, gdy stosujemy kontrast językowy J1 i J2 (wyrazów, form, morfemów, paradygmatów odmiany, konstrukcji składniowych, etc.) w celu unaocznienia i uświadomienia uczącym się tych obszarów J2, które są szczególnie podatne na interferencję (w przypadku konkretnego J1 uczących się), a co za tym idzie na wystąpienie błędów językowych. Kontrast językowy prezentować można na wiele różnych sposobów, także z wykorzystaniem thumaczenia, jednak cel dokonywania przekładu jest w takim przypadku inny - nie przekazujący znaczenie, a ukazujący „brak równoległości w obrębie systemu leksykalnego, morfologicznego, a przede wszystkim składniowego znanych już lub dopiero poznawanych kodów" (Lipińska, Seretny, 2016, s. 30-31). Tłumaczenie dydaktyczne jest jedynie jedną z technik, która jest zazwyczaj stosowana w nauczaniu kontrastywnym. Oznacza to, że J1 uczących się może nie być wykorzystany w danych zadaniach, a ich kontrastywność opierać się będzie na samym materiale, który podlega ćwiczeniu - są to te zagadnienia językowe, które z racji wchodzenia w kontakt J1 i J2 wyłoniono na podstawie wcześniejszej analizy błędów². Zatem odwoływanie się do J1 uczących się ma charakter planowy i celowy, nie służy eksplikacji, a zaakcentowaniu zbieżności i kontrastów językowych, uświadomieniu ich uczniom i uczuleniu na interferencyjne „pułapki językowe”. Celem zaś ćwiczeń kontrastywnych jest podniesienie efektywności rozwijania - kompetencji językowej, co w przypadku J1 i J2, podobnych i spokrewnionych, musi polegać zarówno na walce $\mathrm{z}$ występującymi błędami o charakterze interferencyj-

${ }^{1}$ Kontrastywny oznacza akcentujący wyłącznie różnice pomiędzy systemami językowymi, a konfrontatywny - zarówno różnice, jak i podobieństwa. W glottodydaktyce jednak terminy te występują zamiennie, i tak też są używane w niniejszym tekście.

${ }^{2}$ Autorka przebadała niemal 6 tys. błędów gramatycznych (fleksyjnych i składniowych, z wyłączeniem błędów słowotwórczych) studentów ukraińskojęzycznych w ich polszczyźnie pisanej (Izdebska-Długosz 2021b). Prezentowany w niniejszym artykule podręcznik bazuje na wynikach tychże analiz, dostępnych analiz kontrastywnych języka polskiego i języków wschodniosłowiańskich, a na także kilkunastoletnim doświadczeniu lektorskim w pracy z grupami wschodniosłowiańskimi. 
nym, jak i ich profilaktyce. Aby jednak móc takie ćwiczenia przygotować, nauczający sam musi mieć świadomość tego, co dla użytkowników danego J1 jest problemem. $\mathrm{Z}$ pomocą przychodzi mu zarówno analiza kontrastywna obu języków, jak i analiza błędów językowych faktycznie popełnianych przez uczących się. Stąd tak ważne jest, aby błędy zbierać, zapisywać i analizować. Oczywiście, znajomość J1 uczących się zadania te znacząco ułatwia i pozwala nauczającemu dostrzegać bez wysiłku analitycznego interferencyjne źródła błędów popełnianych przez kursantów. Nauczanie języka obcego w podejściu kontrastywnym jest możliwe jednak także bez znajomości języka ojczystego uczącego się.

Wydaje się, iż dotychczasowe rozważania można podsumować słowami P.D. Madeja:

Analiza kontrastywna oraz analiza błędów to dwa filary podejścia bilingwalnego, bardzo cenne źródło informacji o języku ucznia, ale przede wszystkim o trudnościach, jakie on (uczeń) będzie napotykać w uczeniu się języka (L2), to także cenna pomoc dla nauczyciela w profilaktyce błędów. Analiza kontrastywna jest bardzo przydatna w preparacji odpowiednich ćwiczeń, testów, a nawet tekstów, a techniki kontrastywne można wykorzystywać do prezentacji nowego materiału (konstrukcje gramatyczne, tautonimy, inne), a wszystko po to, aby uczniowi ułatwić świadome pokonywanie trudności w przyswajaniu języka.

(2009, s. 116)

\section{PRZYKLADY ĆWICZEŃ KONTRASTYWNYCH}

Prezentowane poniżej ćwiczenia pochodzą z książki mojego autorstwa Polski dla nas 1. Польский для нас 1. Deklinacja i sktadnia kontrastywnie dla Stowian wschodnich $(A 2-B 2)^{3}$ (Izdebska-Długosz 2021a), zawierającej ćwiczenia kontrastywne dla uczących się JPJO grup studentów wschodniosłowiańskich - użytkowników języka rosyjskiego. Podobnie jak w przypadku wydanego wcześniej zbioru ćwiczeń gramatycznych dla studentów ukraińskojęzycznych (Izdebska-Długosz 2017), tak i w tym, za podstawowe filary pracy nad polską gramatyką w kontraście z J1 przyjęto: uświadamianie różnic między wybranymi elementami J1 i J2 poprzez samodzielną analizę międzyjęzykową, pracę nad błędami interlingwalnymi, intensywny dryl gramatyczny oraz thumaczenie dydaktyczne (Izdebska-Długosz 2018).

Ćwiczenia przeznaczone są dla dorosłych osób rosyjskojęzycznych, uczących się JPJO na poziomach A2-B2. Dotyczą one wszystkich przypadków rzeczownika, przy zwróceniu szczególnej uwagi na połączenia wyrazowe zwłaszcza czasownika z rzeczownikiem oraz przyimka z rzeczownikiem. Są to zatem ćwiczenia składniowe

${ }^{3}$ Planowana jest także druga część publikacji poświęcona fleksji werbalnej i składni (Polski dla nas 2. Польский для нас 2. Koniugacja i składnia kontrastywnie dla Słowian wschodnich (A2-B2)). 
uwzględniające użycie deklinujących się wyrazów w poszczególnych przypadkach: rekcję czasowników i pozostałych części mowy. To właśnie w tych połączeniach uczący się na poziomach A2-B2 popełniają wiele błędów językowych. Posiadając już podstawowy zasób słownictwa oraz znając reguły odmiany wyrazów, nie znają jednak zasad łączenia wyrazów w zdaniach, stąd najczęściej wykorzystują rodzimy schemat. Tak powstają znane wielu osobom błędy: *jechać w Ukrainę; *potrzebować pomoc; *jechać na morze, etc. W książce zamieszczono także rozdziały, których do tej pory brakowało w polskich podręcznikach, a dotyczące różnic $\mathrm{w}$ rodzaju i liczbie podobnie brzmiących, oznaczających te same desygnaty rzeczowników polskich i rosyjskich (np. pol. ten dylemat - ros. эта дилемма). Znajdują się w niej także ćwiczenia dotyczące szyku zdaniowego oraz leksykalne (np. różnice w użyciu zaimków który/jaki). Warto, wydaje się, przyjrzeć się przykładom ćwiczeń kontrastywnych, zarówno tym, które wykorzystują J1 uczących się, jak i tym, w których nie użyto J1.

\section{1. ĆWICZENIA KONTRASTYWNE DWUJĘZYCZNE}

Ćwiczenia tego typu, zawarte w podręczniku, służą przede wszystkim dwóm celom. Jednym z nich jest wprowadzenie danych struktur, drugim zaś - sprawdzenie, czy dokonała się ich automatyzacja.

Ćwiczenia wprowadzające mają charakter analityczny. Studenci powinni pracować samodzielnie, w parach lub grupach. Zadanie zaprezentowane poniżej pozwala na samodzielną analizę podobieństw i różnic między polskimi dopełnieniami narzędnikowymi, a analogicznymi w wybranym przez studentów języku wschodniosłowiańskim.

Przeczytaj poniższy tekst i podkreśl wszystkie formy N. lp. i lm. W poniższej tabeli wypisz czasowniki, z którymi łączy się N. Następnie podaj ich rosyjskie odpowiedniki i sprawdź, z jakimi przypadkami się łączą. Podaj przykłady zdań w obu językach. Przeanalizuj podobieństwa i różnice. Podkreśl kolorem różnice. $Z$ różniącymi się czasownikami ułóż zdania po rosyjsku do tłumaczenia dla koleżanki/kolegi.

Wojtek jest policjantem i kieruje ruchem drogowym. Zwykle jeździ do pracy autobusem, ale dziś pojechat taksówka. W pracy postuguje się kodeksem karnym. Pasjonuje się prawem. Chciatby zostać adwokatem, dlatego dodatkowo studiuje prawo. Ma dwie córki i po pracy zajmuje się nimi $i$ domem. Myje podtogę mopem i zachwyca się porządkiem w domu. Jest osoba zorganizowana. Martwi się swoja młodsza córka, która właśnie zaraziła się wirusem i choruje. Wojtek się nia opiekuje. Czesze jej włosy gruba szczotka i wyciera nos chusteczka. Młodsza córka rządzi całym domem! Zwykle rysuje kredkami w swoim pokoju, ale kiedy choruje, chce bawić się z rodzicami $i$ kierować wszystkimi tak jak jej tato w pracy. Chwali się swoim tata w szkole. Opowiada, że jest silny, odważny i goni złodziei. Ania pasjonuje się lotnictwem. Chciałaby być pilotem i latać samolotami. Na razie musi bawić się zabawkowymi modelami. Ma tylko 4 lata. 


\begin{tabular}{|l|c|}
\hline Język polski & Wybrany język wschodniosłowiański \\
\hline Wojtek jest policjantem (jest+N.) & Войтек - полицейский (brak czasownika być, M.) \\
& \\
\hline
\end{tabular}

\section{Źródło: opracowanie własne}

Samodzielne wykonanie ćwiczenia przez studentów i zreferowanie jego wyników dają gotową bazę materiału do utrwalenia. Przy czym automatyzacja danych form nie wymaga już konfrontacji z J1.

Materiał językowy w poniższym ćwiczeniu to złożone $\mathrm{z}$ dwóch podanych członów zdania polskie, a różnice między J1 i J2 dotyczą polskich dopełnień dopełniaczowych. Dane językowe do samodzielnej analizy mogą być zatem wprowadzane nie tylko za pomocą tekstu, ale również na poziomie pojedynczych zdań.
Połącz logicznie wyrażenia z kolumn, a następnie wypełnij poniższą tabelę.
0. Chętnie spróbuję
1. Ojciec jest dumny
2. Używałaś już
3. Byłyśmy zadowolone
4. Nie dotykaj
5. Nigdy nie odmawiaj
6. Korzystałaś już
7. Naprawdę cieszę się z
a) ze standardu hotelu.
b) polskiego jedzenia.
c) przyjacielowi pomocy.
d) kontaktu!
e) ze swojego syna.
f) tego nowego kremu?
g) twojego sukcesu
h) ze swojego nowego komputera?

\begin{tabular}{|l|l|}
\hline \multicolumn{1}{|c|}{ Język polski } & \multicolumn{1}{|c|}{ Wybrany język wschodniosłowiański } \\
\hline $\begin{array}{l}\text { 0. spróbować jedzenia (+D.) } \\
\text { Chcę spróbować tego chleba. }\end{array}$ & $\begin{array}{l}\text { попробовать еду (+B.) } \\
\text { Я хочу попробовать этот хлеб. }\end{array}$ \\
\hline 1. & \\
\hline
\end{tabular}

Źródło: opracowanie własne

Ćwiczenia bilingwalne znakomicie nadają się także do ewaluacji. Tłumaczenia całych zdań oznajmujących i pytających z języka rosyjskiego na polski są dobrym sprawdzeniem tego, jak przebiegła wcześniejsza automatyzacja. Uwzględniają one bowiem ,pułapki językowe”.

Niekiedy tłumaczeniu podlegają nie tylko całe zdania, ale także pojedyncze wyrazy lub wyrażenia, którymi należy uzupełnić podane frazy w języku polskim. W poniższym ćwiczeniu, dotyczącym odmiennego rodzaju podobnie brzmiących i oznaczających to samo rzeczowników polskich i rosyjskich, trzeba także uważać na prawidłową formę thumaczonych i wstawianych wyrazów. Wiadomo bowiem, że 
problemy z rodzajem są większe, jeśli dany wyraz występuje w przypadku innym niż mianownik. Tego typu ćwiczenia - połowicznie translacyjne - S.P. Kaczmarski określa jako tzw. transferencję gramatyczną, oznaczającą ,implantację (tj. osadzanie) znaczeń języka źródłowego w tekście języka docelowego" (1988, s. 51, 2002b).

Uzupełnij zdania przetłumaczonymi rzeczownikami w odpowiedniej formie.

0 . Widzieliście już (центр) centrum stolicy?

1. Do ..(который лицей) w Krakowie chodziłaś?

2. Opowiedz mi o (цель) w życiu.

3. Byłeś już może u (новый дантист)?

4. Pokażcie mi (новая программа) festiwalu.

5. $\mathrm{O}$ (эта поэма) napisałem w szkole wypracowanie.

6. Neil Armstrong był . (известный космонавт).

7. Nie znałem (эта парадигма).

8. Gdybym nie czuł (эта боль), poszedłbym na trening.

Źródło: opracowanie własne

Innym przykładem tego typu jest ćwiczenie, w którym użyto nie rosyjskich, a ukraińskich wyrazów. Dotyczy ono różnic w rodzaju rzeczowników polskich i ukraińskich o podobnym brzmieniu i tożsamym znaczeniu.

Wstaw wyrazy z nawiasów, tłumacząc je z języka ukraińskiego.

0 . Widziałam w jego domu (довга тераса) długi taras.

1. W TV ostrzegają przed (небезпечна атака) tego przestępcy.

2. Wlali ci do oka dużo (атропін) ?

3. Naukowcy nie wykonali dostatecznych (аналіз)

4. Kto jest autorem (ця цитата) ?

5. Oni nie mają (не будь-які проблеми)

6. Nie znam (освітня система) Ukrainy.

7. Nigdzie poza Afryką nie widziałem tak (великий простір) !

8. Paweł nie opowiadał nam (цей анекдот)

Źródło: opracowanie własne

\section{2. ĆWICZENIA KONTRASTYWNE JEDNOJĘZYCZNE}

Ćwiczenia tego typu służą głównie automatyzacji wyróżnionych wcześniej w toku samodzielnej analizy tych polskich form, które w jakimś aspekcie różnią się od wschodniosłowiańskich i zwykle sprawiają dużo problemów studentom. Dryle to zwykle uzupełnianie luk w zdaniach lub w tekście, ale także kontrast 
dwóch form: poprawnej i błędnej. Podana forma błędna pochodzi z badań empirycznych nad polszczyzną osób ze Wschodu.

Podkreśl poprawne formy.

0 . pozdrowienia twojej rodzinie / dla twojej rodziny

1. Mam dobry pomysł na to / o tym.

2. Jaka jest przyczyna tego / od tego?

3. SPA jest miejscem odpoczynku / dla odpoczynku.

4. Szukam miejsca dla stażu / stażu.

5. Jaki mamy budżet dla podróży / podróży?

6. Mam jeszcze wariant pobytu / dla pobytu.

7. Ceny na samochody / samochodów są niskie.

Źródło: opracowanie własne

Ćwiczeniami silnie automatyzującymi są te, w których ustnie powtarza się dany wzorzec zdaniowy z odmiennym wypełnieniem leksykalnym. Procedura znana przede wszystkim z metody audiolingwalnej mimo pozornej monotonii podoba się studentom, a przede wszystkim wykazuje się wysoką efektywnością. Rzecz jasna, ćwiczeniu podlegają różniące się od wschodniosłowiańskich dopełnienia - w poniższym przykładzie - narzędnikowe.

Poćwicz ustnie, wstawiając wyrazy z nawiasów w odpowiedniej formie.

1. Męczę się (hałas, ta rozmowa, bałagan, krzyki dzieci, chaos, jedzenie, trening, kłótnie, bieganie).

2. Oni różnią się (wzrost, wiek, charakter, osobowość, wrażliwość, inteligencja, wiedza, kolor oczu, tusza).

3. Dyktator gardzi (ludzie, inni, biedni, głodni, naród, poddani, przeciwnicy, służący).

4. Rozczarowałem się (przyjaciel, kolega, szef, ten film, nowa płyta, ta wiadomość, przyjaciółka, twoje zachowanie, swoje dziecko).

5. Denerwuję się (egzamin, rozmowa kwalifikacyjna, wystąpienie publiczne, referat, rozmowa z szefem, kłótnia, wizyta u lekarza, wyniki badań, pobranie krwi, operacja).

6. Jestem zainteresowany (ta praca, ta oferta, zakup tego samochodu, kierunek studiów, ta dziedzina, nauka, nowy film, ta książka).

7. Przejmuję się (twoje słowa, wojny, rozmowa z szefem, egzamin, te wspomnienia, bieda, głód, sytuacja na świecie).

8. Jestem rozczarowana (twoja postawa, wasza opinia, twoje zachowanie, twój postępek, twoje słowa, wasze oceny, swój wynik na egzaminie).

Źródło: opracowanie własne

Wysoce efektywne, choć jedne z trudniejszych, są kontrastywne ćwiczenia ukierunkowane na mediację językową. Fragment poniższego dotyczy polskich dopełnień celownikowych. Pod każdą krótką wypowiedzią zamieszczono pytanie, 
zawierające problematyczny dla studentów ze Wschodu czasownik (ma inną niż celownikową rekcję w językach wschodniosłowiańskich). Odpowiedź wymaga zatem wyrażenia tej samej treści w innej, narzuconej gramatycznie formie.

Przeczytaj poniższe wypowiedzi i odpowiedz na pytania przy tekstach.

1. Marcin, 18 lat: Gdy Polacy grali z Niemcami, to oczywiście bytem za naszymi, ale ponieważ przez 10 lat mieszkatem w Berlinie, to bytem też za Niemcami. Wygrali Niemcy.

Komu kibicował Marcin?

2. Alina, 85 lat: Mój Maciuś trzymat rower u mnie na klatce schodowej. Niczym go nie przypinat, gdy do mnie przychodził. I dziś kochany wnuczek mi mówi, że roweru nie ma. Zabrali! A kto? Nie wiem. Komu ukradziono rower?

3. Wlodzimierz, 64 lata: Co roku jeżdże do sanatorium i tam spaceruję z innymi pacjentami. Chodzę z kuracjuszami $i$-oczywiście kuracjuszkami też - na dancingi. Ogólnie, dobrze się bawimy. Komu Włodzimierz towarzyszy w sanatorium?

4. Basia, 30 lat: Jestem pielęniarka i doskonale wiem, jak się chronić przed zachorowaniem na koronawirusa. Bardzo częste mycie rąk, zakrywanie nosa i ust $w$ miejscach publicznych - to absolutna konieczność.

Czemu zapobiegają działania proponowane przez Basię?

Źródło: opracowanie własne

Podobne są ćwiczenia zawierające dłuższe teksty. Wymaga się zrozumienia ich i odpowiedzi na zadane do nich pytania, które sformułowano w sposób narzucający użycie innych niż w tekście konstrukcji składniowych. Poniższy przykład dotyczy dopełnień biernikowych, głównie przyimkowych, w których studenci ze Wschodu popełniają dużo błędów.

Przeczytaj poniższy tekst i odpowiedz na pytania do niego.

Ostatnio w Polsce głośna była afera zwiąana z odebraniem właścicielowi pumy, która trzymat $w$ domu. Puma mogła mieszkać w domu, spać w tóżku, bawić się z domownikami. Była zdrowa i zadbana. Po jej odebraniu, opiekun prosił odpowiednie organy, by zwrócono mu zwierzę. Twierdzit, że policja użyła wobec niego sity i przemocy. Jeździt do ZOO i starat się utrzymywać kontakt z puma. Bat się, że puma go zapomni. Caly czas walczy, żeby puma do niego wróciła. Hodowanie dzikich zwierzat przez osoby prywatne jest prawnie zakazane w Polsce.

1. O co dbał mężczyzna?

2. Na co opiekun pozwalał pumie?

3. O co opiekun zwrócił się do odpowiednich organów?

4. O co mężczyzna oskarżył policjantów?

5. O co starał się mężczyzna?

6. O co się niepokoi?

7. O co walczy opiekun pumy?

8. Jakie zwierzęta może w Polsce hodować w domu osoba prywatna, a jakich nie? 
Część ćwiczeń zawartych w książce dotyczy także błędów pragmatyczno-językowych, a za takie należy uznać błędy w zwrotach bezpośrednich z użyciem form w polskim wołaczu.

Przeczytaj fragmenty wypowiedzi i zastanów się, gdzie popełniono błąd. Sformułuj zasady.

0. Monika (lat 17) do swojego przyjaciela: Filipie, podaj mi ten zeszyt! Filip! - rówieśnicy, szczególnie osoby młode nie używają form W. zwracając się do siebie w rozmowie, tylko imion w M.

1. Igor (lat 19) do swojej lektorki: Pani Beato, czy można już pisać?

2. Kasia (lat 9) do mamy: Matko, czy jest już obiad?

3. Anna (lat 30) do nieznajomej kobiety w biurze: Pani Basiu, czy sa już gotowe dokumenty?

4. Maksym (lat 20) z Ukrainy do kolegi z grupy na lektoracie języka polskiego: Panie Andrieju, co byto na zadanie domowe?

\section{Źródło: opracowanie własne}

W podręczniku poruszono także niektóre zagadnienia leksykalne. Poglądowo przedstawiono zestawienia najmocniej lapsogennych wyrazów/wyrażeń (w serii „Małe - ważne słówka”) - jak w poniższym przykładzie.

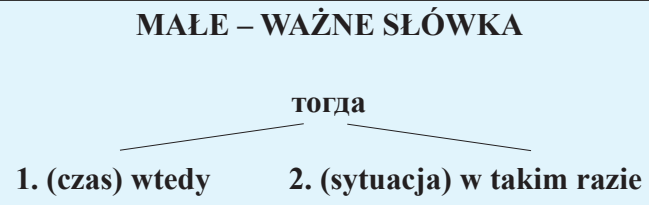

1. Я тогда не учил польский. Когда? Тогда (в 2018 году). Wtedy nie uczyłem się polskiego. 2. - Напишите, пожалуйста, письмо директору школы. - Хорошо, тогда напишу. - Proszę napisać list do dyrektora. - Dobrze, w takim razie napiszę.

\section{Źródło: opracowanie własne}

Przedstawiono także ważniejsze kwestie użycia konkretnych form językowych w ramkach - tych konstrukcji, w których Słowianie wschodni popełniają najwięcej błędów. Poniższy przykład odnosi się do wschodniosłowiańskich nieosobowych konstrukcji celownikowych, którym w polszczyźnie odpowiadają czynne konstrukcje mianownikowe.

\begin{tabular}{|c|c|}
\hline Ros. & Pol. \\
\hline Мне было интересно. & (ja) Byłem/byłam zainteresowany/a. \\
\hline Нам нужен отдых. & (my) Potrzebujemy odpoczynku. \\
\hline Тебе нужно выучить. & (ty) Musisz się nauczyć. \\
\hline Студенту нужно больше учиться. & (on) Student musi się więcej uczyć. \\
\hline $\begin{array}{l}\text { Nieosobowa konstrukcja z osobą } \\
\text { w celowniku. }\end{array}$ & $\begin{array}{l}\text { Osobowa konstrukcja czynna z osobą } \\
\text { w mianowniku. }\end{array}$ \\
\hline
\end{tabular}




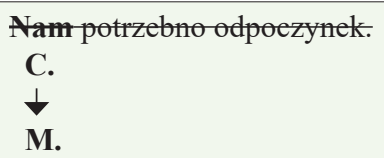

Źródło: opracowanie własne

\section{ZAKOŃCZENIE}

W dydaktyce polskiej gramatyki dla uczących się ze Wschodu znakomicie sprawdza się kontrast językowy z J1. Aby jednak nauczanie tego typu można było nazwać kontrastywnym konieczne jest w tworzeniu pomocy dydaktycznych oparcie się na analizie kontrastywnej J1 i J2 z jednej strony, a na analizie błędów językowych $-\mathrm{z}$ drugiej. Wówczas możliwe jest przygotowanie materiałów dydaktycznych celowanych w występujące empirycznie trudności językowe tej grupy odbiorców. Znajomość J1 uczących się pomaga w rozpoznawaniu źródeł błędów i korzystaniu ze zdobyczy językoznawstwa kontrastywnego, jednak - jak starano się wykazać - można nauczać w kontraście, nie posługując się J1 grupy. Oddając pole działania samym uczącym się, którzy samodzielnie dokonują analiz kontrastów językowych, możemy skoncentrować się na automatyzacji problematycznych form i konstrukcji oraz ich ewaluacji.

\section{BIBLIOGRAFIA}

Allen J.P.B., 1983, Gramatyka pedagogiczna, w: J.P.B. Allen, S.P. Corder, A. Davies (red.), Kurs edynburski językoznawstwa stosowanego. Tom II. Techniki w językoznawstwie stosowanym, Warszawa, s. 61-83.

Arabski J., 1980, Warunki i sposoby występowania interferencji, w: J. Arabski (red.), Wybrane metody glottodydaktyki, Katowice, s. 9-19.

Bednarska K., 2014, Rola transferu językowego w nauczaniu języka polskiego Słoweńców, Łódź.

Biełocka T., 1997, Trudności młodzieży grodzieńskiej w przyswajaniu rodzaju gramatycznego niektórych rzeczowników polskich, w: B. Janowska, J. Porayski-Pomsta (red.), Język polski w kraju i za granica, t. II, Warszawa, s. 24-30.

Czochralski J.A., 1979, O interferencji językowej, w: F. Grucza (red.), Polska myśl glottodydaktyczna 1945-1975. Wybór artykułów z zakresu glottodydaktyki ogólnej, Warszawa, s. 521-536.

Doros A., Łużny S., 1965, Zapobieganie błędom syntaktycznym i stylistycznym przy nauczaniu języka rosyjskiego, Warszawa.

Grochowski L., 1978, Metodyka nauczania języka rosyjskiego, Warszawa.

Harczuk Z., 1972a, Interferencja języka polskiego w procesie nauczania języka rosyjskiego, Warszawa. 
Harczuk Z., 1972b, O konsekwencjach dydaktycznych interferencji w nauczaniu języka rosyjskiego, w: S. Siatkowski (red.), Podstawy naukowe nauczania języka rosyjskiego, Warszawa, s. 204-213.

Izdebska-Długosz D., 2015, Specyficzne problemy nauczania języka polskiego jako obcego w środowisku ukraińskojęzycznym, w: D. Gonigroszek (red.), Języki obce i kultura: Nowe konteksty edukacyjne, Piotrków Trybunalski, s. 315-323.

Izdebska-Długosz D., 2017, Po polsku bez błędu. Zbiór ćwiczeń z gramatyki języka polskiego dla studentów ukraińskojęzycznych (A1-B1), Rzeszów.

Izdebska-Długosz D., 2018, Konfrontatywność, dryl i tlumaczenie - koncepcja ksiązki „,Po polsku bez błędu. zbiór ćwiczeń z gramatyki języka polskiego dla studentów ukraińskojęzycznych (A1-B1)”, w: A. Krawczuk, I. Bundza (red.), Polonistyka w XXI wieku: między lokalnym a globalnym, Kijów, s. 379-392.

Izdebska-Długosz D., 2021a, Polski dla nas 1. Polskiy dlia nas 1. Deklinacja i składnia kontrastywnie dla Stowian wschodnich (A2-B2), Kraków.

Izdebska-Długosz D., 2021b, Błędy gramatyczne w polszczyźnie studentów ukraińskojęzycznych, Kraków.

Jabłońska O., 2004, Szkolnictwo polskie na Ukrainie. Metody i problemy nauczania języka polskiego, w: A. Dąbrowska (red.), Wrocławska dyskusja o języku polskim jako obcym, Wrocław, s. 123-131.

Kaczmarski S.P., 1988, Wstęp do bilingwalnego ujęcia nauki języka obcego, Warszawa.

Kaczmarski S.P., 2002a, Gramatyka a funkcjonalno-komunikacyjne nauczanie języka obcego, „Języki Obce w Szkole", nr 2, s. 15-19.

Kaczmarski S.P., 2002b, Transferencja gramatyczna w glottodydaktyce. „Języki Obce w Szkole”, nr 2, s. 19-22.

Kaczmarski S.P., 2003, Język ojczysty w nauce języka obcego - kilka refleksji, „Języki Obce w Szkole", nr 1, s. 14-19.

Karolczuk M., 2006, Gramaticheskaya interferentsya v processe obuchenya russkoi rechi polskikh studentov-filologov, Białystok.

Komorowska H., 1980, Nauczanie gramatyki języka obcego a interferencja. Audiolingwalizm, kognitywizm, interferencja, Warszawa.

Korzeniewska-Rogalewicz J., 1986, Bład leksykalny a dydaktyka języka obcego. Na materiale języka rosyjskiego, Warszawa.

Kowalikowa J., 1992, Zagadnienia komparatystyki w nauczaniu języka polskiego w uniwersytecie zagranicznym, w: S. Grabias (red.), Język polski jako język obcy, Lublin, s. 51-58.

Krawczuk A., 2005, Trudne miejsca w gramatyce polskiej dla Ukrainców (w zwiazku z przygotowywaniem podręcznika „Polska fleksja z ćwiczeniami dla Ukraińców”), w: P. Garncarek (red.), Nauczanie języka polskiego jako obcego i polskiej kultury w nowej rzeczywistości europejskiej, Warszawa, s. 491-497.

Krawczuk A., 2011, Błędy językowe w polszczyźnie Ukraińców powodujące zakłócenia komunikacji z Polakami, w: I. Masojć, H. Sokołowska (red.), Tożsamość na styku kultur, Vilnius, s. 480-494.

Krucka B., 1995, Rusycyzmy składniowe w języku Polaków ze Wschodu na tle polsko-rosyjskich kontrastów językowych, w: J. Mazur (red.), Kształcenie sprawności komunikacyjnej Polaków ze Wschodu, Lublin, s. 115-123.

Krzeszowski T.P., 1979a, Interjęzyk i kontrastywna gramatyka generatywna, w: F. Grucza (red.), Polska myśl glottodydaktyczna 1945-1975. Wybór artykułów z zakresu glottodydaktyki ogólnej, s. 586-596.

Krzeszowski T.P., 1979b, Rola znajomości gramatyki języka ojczystego w nauce języka obcego. „Przegląd Glottodydaktyczny”, t. 3, s. 7-17.

Lipińska, E., Seretny, A., 2016, Tłumaczenie w nauczaniu/uczeniu się języka obcego - od słowa do tekstu, w: A. Seretny, E. Lipińska (red.), Ttumaczenie dydaktyczne w nowoczesnym kształceniu językowym, Kraków, s. 23-35. 
Madej P.D., 2009, Ttumaczenie bezpośrednie jako metoda nauki języka obcego. Referat w: V Międzynarodowa Konferencja Edukacyjna: „Języki obce w kontekście wspótczesnych wyzwań i perspektyw", Ustroń, s. 113-119.

Marton W., 1979, Pedagogiczne implikacje studiów kontrastywnych, w: F. Grucza (red.), Polska myśl glottodydaktyczna 1945-1975. Wybór artykułów z zakresu glottodydaktyki ogólnej, Warszawa, s. 607-617.

Mazur J., 1995, Językowe i kulturowe uwarunkowania ksztatcenia sprawności komunikacyjnej, w: J. Mazur (red.), Kształcenie sprawności komunikacyjnej Polaków ze Wschodu, Lublin, s. $27-37$.

Mazur J. (red.), 1992, Problemy ksztatcenia Polaków ze Wschodu, Lublin.

Mazur J. (red.), 1993, Metodyka ksztatcenia językowego Polaków ze Wschodu, Lublin.

Mazur J. (red.), 1995, Ksztatcenie sprawności komunikacyjnej Polaków ze Wschodu, Lublin.

Mazur J. (red.), 1996, Kształcenie rodaków ze Wschodu w Polsce (1989-1995), Lublin.

Otwinowska-Kasztelanic A., 2009, Rozwój różnojęzyczności w ksztatceniu neofilologicznym w świetle teorii afordancji językowych, w: H. Komorowska (red.), Ksztatcenie językowe w szkolnictwie wyższym, Warszawa, s. 189-205.

Paradowski M.B., 2006, Uczyć, aby nauczyć - rola języka ojczystego w gramatyce pedagogicznej w implikacje dla dydaktyki języków obcych, w: J. Krieger-Knieja, U. Paprocka-Piotrowska (red.), Komunikacja językowa w społeczeństwie informacyjnym - nowe wyzwania dla dydaktyki języków obcych, Lublin, s. 125-138.

Seretny A., 2018, W pułapce interkomprehensywnej komunikatywności, w: A. Krawczuk, I. Bundza (red.), Polonistyka w XXI wieku: między lokalnym a globalnym, Kijów, s. 291-303.

Siatkowski S., 1976, Językoznawstwo a problemy nauczania języków obcych, w: S. Siatkowski (red.), Nauczanie języka rosyjskiego a językoznawstwo i psychologia, Warszawa, s. 16-27.

Skrundowa Z., 1985, Nauczanie gramatyki języka rosyjskiego. Warszawa.

Dominika Izdebska-Dtugosz

\section{THE DIDACTICS OF POLISH DECLENSION AND SYNTAX IN GROUPS OF EAST SLAVIC STUDENTS}

Keywords: Polish as a Foreign Language, linguistic contrast, contrastive teaching, declension, syntax, Russian-speaking students, students from the East

Summary. In this paper, teaching Polish as a Foreign Language to adults from the east, that is, the inhabitants of former Soviet republics speaking Russian as their first or second language is used an example of the didactics of Polish declension and syntax from the perspective of contrastive linguistics. While presenting the theoretical context of didactics contrasted with L1, it is stressed that nowadays that the contrastive analyses of L1 and L2, error analysis and the knowledge of the phenomenon of interference are all employed in teaching. The postulate of applying a confrontative approach in teaching PFL to people from the east, which is which is supported by Polish research tradition, is presented in the article. In the article, the techniques of the Polish didactics of declension and syntax contrasted with the Russian language have been derived from the book Polski dla nas 1 [Polish for us 1]. Польский для нас 1. Deklinacja i składnia kontrastywnie dla Stowian wschodnich $(A 2-B 2)$ [Declension and syntax for East Slavic students from the contrastive perspective (A2-B2)]. The techniques have been divided into two groups: monolingual exercises and bilingual exercises. It has been stressed that the knowledge of L1 of the students taught by a tutor is significantly facilitated by teaching with the use of the contrastive approach, yet it is not a condition sine qua non for such type of didactics. 